\title{
In vitro effects of 2-methyl-3-propylbutane-1,4-diol Purified From Alstonia Boonei on Erythrocyte Membrane Stabilization and Mitochondrial Membrane Permeabilisation
}

John Oludele Olanlokun ( $\square$ jodel72000@yahoo.com )

University of Ibadan

David Popoola

University of Ibadan

Olusola Bodede

University of KwaZulu-Natal

Thomas Idowu

Obafemi Awolowo University

Roshila Moodley

University of KwaZulu-Natal

Olufunso Olorunsogo

University of Ibadan

Olubukola Titilope Oyebode

University of Ibadan

\section{Research Article}

Keywords: Alstonia boonei, Mitochondria, Cytochrome c, Lipid peroxidation, Mitochondrial adenosine triphosphatase

Posted Date: January 17th, 2022

DOI: https://doi.org/10.21203/rs.3.rs-1236651/v1

License: (9) This work is licensed under a Creative Commons Attribution 4.0 International License. Read Full License 


\section{Abstract}

A recent review on the ethnomedicinal, chemical, pharmacological, and toxicological properties of Alstonia boonei revealed that the plant's potential in the treatment and management of a range of diseases. However, most of these pharmacological effects are only traceable to crude form of the plant extract and not specific natural products In this study, the membrane stabilizing activity, mitochondrial membrane permeability transition pore opening, cytochrome $c$ release, mitochondrial ATPase activity and prevention of mitochondrial lipid peroxidation activity of 2-methyl-3-propylbutane-1,4-diol (MPBD) isolated from $A$. boonei were determined. The results showed MPBD significantly $(P<0.05)$ prevented peroxidation of mitochondrial membrane lipids and hemolysis using both the heat-induced and hypotonic solution-induced membrane stabilization assays. On the other hand, the compound caused large amplitude swelling of rat liver mitochondria in the absence of calcium, significant $(P<0.05)$ cytochrome $c$ release and enhancement of mitochondrial ATPase activity in vitro. Our findings suggest that MPBD showed characteristic biological properties useful in modulating cell death.

\section{Introduction}

Alstonia boonei is well known as a perennial tree with pharmacological properties. Several bioactive compounds with their pharmacological effects have been purified from the plant. Alkaloids such as echitamine and related compounds have been purified from this compound ${ }^{1}$. Recently, we purified tetrahydro-4-hydroxy-10methoxy-6, 14-dimethyl-15-m-tolylpentadec-13-enyl) pyran-2-one and isobutyryl acetate from the plant and reported their biological effects on some mitochondrial proteins ${ }^{2}$. The mitochondrial permeability transition (mPT) pore is a high conductance channel in the mitochondria whose short opening serves a physiological role in mitochondria. However, long term opening results in mitochondrial depolarization, low mitochondrial membrane potential, reversal of mitochondrial ATP synthase function to phosphatase, oxidative stress, mitochondrial swelling and release of proapoptotic proteins, e.g., cytochrome $\mathrm{c}$ into the cytosol ${ }^{3-4}$. We have previously reported the influence of plant extract from Alstonia boone $I^{5}$ and a medicinal plant cocktail called 'alpha stone' plants on mitochondrial permeability transition pore, the physiological, pathological and pharmacological effects ${ }^{6}$. The mitochondrial permeability transition pore has evolved as a pharmacological target in a variety of diseases. An extensive list of drugs has been reported to delay or prevent permeability transition pore opening, which invariably can be used to prevent tissue degeneration ${ }^{7}$. There is also a quest to find drugs that can cause large amplitude swelling of the mitochondria via induction of the permeability transition pore opening. This is helpful in situations where apoptosis is down regulated.

Although, the exact molecular components of the pore remains elusive, there are different plausible proposals that certain proteins such as the Voltage Dependent Anion Channel (VDAC) of the outer mitochondrial membrane, the Adenine Nucleotide Translocase (ANT) of the inner mitochondrial membrane and cyclophilin $D$ are components of the pore ${ }^{8-10}$. However, recent evidence has shown the involvement of ATP synthase, a key player in ATP synthesis, in permeability transition pore opening ${ }^{11}$. 
Biological agents that inhibit mitochondrial respiration, induce mitochondrial swelling or loss of the mitochondrial membrane potential can result in cellular energetic failure via ATP hydrolysis by increasing the cytosolic concentration of inorganic phosphate, $\mathrm{Ca}^{2+}$ overloading, loss of osmotic regulation and generation of reactive oxygen species ${ }^{12}$.

An increase in reactive oxygen species has been shown to elicit membrane damage via peroxidation of membrane lipids ${ }^{13}$. Cytochrome $c$ release and increase in the cytosolic concentration of inorganic phosphate, among other factors, are important predicators of apoptosis. Apoptosis is a crucial biological event in eukaryotic cells, necessary to maintain tissue homeostasis. Crude extracts of medicinal plants

and their secondary metabolites have been shown to induce cell death ${ }^{14-15}$. A. boonei is a medicinal plant that is commonly used for the treatment of several ailments including, rheumatic and inflammatory disorders ${ }^{16}$.

In this study, we present a new compound purified from the methanol fraction of $A$. boonei and some of its biological properties including its interaction with erythrocyte membranes. Erythrocytes have organized membrane structures, which interact and react to drugs and drug candidates ${ }^{17}$. Natural products such as saponins have been shown to have hemolytic properties via the release of hemoglobin from the red blood cells into the surrounding fluids ${ }^{18}$. While several studies have established a strong link between structure-activity relationships on bioactive compounds, it has been shown that the role played by functional groups of these compounds may be critical to their biological functions. Although, several studies have established the presence of some natural products in Alstonia boonei and their pharmacological response has been well studied, it is difficult to purify and identify all phytochemicals present in a medicinal plant in a single study. Moreover, most pharmacological studies of medicinal plants terminates at the extract and fraction level. Hence, it is better to further purify extracts of medicinal plants to determine the biological effects of new compounds isolated and to ascribe the biological effects of these medicinal plant to specific phytochemicals and possibly optimize their pharmacological use. It is in this regard, we investigated the erythrocyte membrane stabilizing and mitochondrial pore opening potential of this new phytochemical from the methanol fraction of $A$. boonei stem bark extract.

\section{Experimental}

\section{Extraction of the stem bark of Alstonia boonei}

The stem bark of $A$. boonei were peeled from the plant growing in an uncultivated farmland in Ibadan. Samples were authenticated by Mr. Omotayo F.L., Ekiti State University Herbarium and a specimen (UHAE 013) was deposited in the herbarium. The stem bark (100 g) were air-dried at room temperature for five weeks, crushed and soaked in methanol $(\mathrm{MeOH})$ for $72 \mathrm{~h}$ with constant shaking. The extract was sieved and concentrated using a rotary evaporator at $40^{\circ} \mathrm{C}$ under reduced pressure.

\section{Purification of the bioactive compound}


The $\mathrm{MeOH}$ fraction (2g) was partitioned successively using ethylacetate (EtOAc, 100\%), EtOAc: $\mathrm{MeOH}$ (1:1) and $\mathrm{MeOH}(100 \%)$ using vacuum liquid chromatography. Based on biological activity, using the mitochondrial permeability transition pore opening, the EtOAc-MeOH fraction was further purified using column chromatography starting with $100 \%$ chloroform that was stepped by $10 \%$ to $100 \%$ EtOAc. Thereafter, the polarity of the solvent system was increased by adding $\mathrm{MeOH}$ at $5 \%$ intervals until $20 \%$ $\mathrm{MeOH}$ was added. Eight fractions of each were collected for each eluent step. These fractions were pooled based on their thin layer chromatography (TCL) profiles to give fractions $A(1-9), B(10-27), C(28-$ 42), $D(43-72)$ and $E(73-104)$. Fraction $C$ was further purified using preparative TLC to yield 2-methyl-3propylbutane-1,4-diol. The purified compound was subjected to ${ }^{1} \mathrm{H},{ }^{13} \mathrm{C}, \mathrm{COSY}, \mathrm{HMBC}$ and HSQC spectroscopic analyses for full identification and characterization.

\section{Ethical consideration}

All animals used for this experiment were handled in accordance with the rules and regulations for management of animals used in research as contained in the Guide for the Care and Use of Laboratory Animals ${ }^{19}$. Furthermore, this study was approved by the University of Ibadan Animal Use and Care Research Ethics (ACUREC) and an approval number UI-ACUREC/18/0053 was assigned to the study. Furthermore, this study was carried out in compliance with the ARRIVE guidelines and in accordance with relevant guidelines and regulations. The use of this medicinal plant complies with local and national regulations. Spectroscopic data generated on the purification of the natural product used in this study are included in this published article as supplementary information files.

\section{Isolation of mitochondria from rat liver}

Mitochondria were isolated from Wistar rat liver according to a previously described method by Johnson and Lardy ${ }^{20}$. The rats were sacrificed by cervical dislocation, dissected, the liver was removed, rinsed in isolation buffer ( $210 \mathrm{mM}$ mannitol, $70 \mathrm{mM}$ sucrose, $5 \mathrm{mM} \mathrm{HEPES-KOH} \mathrm{(pH} \mathrm{7.4)} \mathrm{and} 1 \mathrm{mM} \mathrm{EGTA}$ ), and a $10 \%$ minced suspension of the liver in isolation buffer was homogenised on ice-cold medium. The homogenate was loaded into a cold centrifuge (Sigma 3-30K, Germany) and spun twice at $2300 \mathrm{rpm}$ for 5 min each to remove cell and nuclear debris and unbroken cells. The supernatant was spun at $13000 \mathrm{rpm}$ for $10 \mathrm{~min}$ to sediment the mitochondria. Mitochondria pellets were washed twice with washing buffer (210 mM mannitol, $70 \mathrm{mM}$ sucrose, $5 \mathrm{mM} \mathrm{HEPES-KOH} \mathrm{(pH7.4)} \mathrm{and} \mathrm{0.5 \%} \mathrm{BSA)} \mathrm{at} \mathrm{12000rpm} \mathrm{for} 10 \mathrm{~min}$ each time after which, mitochondria were dispensed into aliquots in Eppendorf tubes with suspension buffer (210 mM mannitol, $70 \mathrm{mM}$ sucrose and $5 \mathrm{mM}$ HEPES-KOH (pH7.4)). Mitochondria used for ATPase activity were isolated similarly except sucrose buffer $(25 \mathrm{M})$ was used throughout.

\section{Mitochondrial Protein determination}

Mitochondrial protein was determined as previously described using bovine serum albumin (BSA) as the standard ${ }^{21}$. Mitochondria (10 $\left.\mu \mathrm{l}\right)$ were pipetted into $990 \mu \mathrm{l}$ of distilled water and $3 \mathrm{ml}$ of a 100:1:1 solution of $2 \% \mathrm{Na}_{2} \mathrm{CO}_{3}, 2 \% \mathrm{Na}-\mathrm{K}$ tartrate and $2 \% \mathrm{CuSO}_{4} \cdot 5 \mathrm{H}_{2} \mathrm{O}$ was added. The mixture was incubated at 
room temperature for $10 \mathrm{~min}$, after which, a five-fold diluted Folin-Ciocalteau (0.3 ml) was added. This was incubated at room temperature for $30 \mathrm{~min}$, vortexed and the absorbance was read at $750 \mathrm{~nm}$ using a spectrophotometer (752N UV-Visible spectrophotometer, China). Mitochondrial protein was quantified from the BSA standard curve.

\section{Mitochondria permeability transition pore opening}

The opening of the mitochondrial pore by MPBD was assessed according to the method described by Lapidus and Sokolove ${ }^{22}$. This method was first used to determine the quality and suitability of the isolated mitochondria for mPT assay as follows: Mitochondria protein $(0.4 \mathrm{mg} / \mathrm{mL})$ was incubated in suspension buffer in the presence of rotenone $(0.8 \mu \mathrm{M})$ for $3.5 \mathrm{~min}$ after which, succinate $(5 \mathrm{mM}$ sodium succinate) was added and the absorbance was monitored at $540 \mathrm{~nm}$ for $12 \mathrm{~min}$ at $30 \mathrm{~s}$ interval.

Furthermore, the pore opening effect of calcium; a standard pore opening inducer was monitored using the same mitochondria protein incubated in suspension buffer in the presence of rotenone for 3 min after which, calcium $\left(3 \mu \mathrm{M} \mathrm{CaCl}_{2}\right)$ was added. Thirty seconds later, succinate was added to energise the medium and the absorbance was read. Spermine reversal of calcium-induced opening was done by incubating the same mitochondria protein quantity in suspension buffer in the presence of rotenone and $5 \mathrm{mM}$ spermine for $3 \mathrm{~min}$. Thereafter, calcium was added. The reaction medium was energised with succinate 30s later and the absorbance was monitored for $12 \mathrm{~min}$ at 30 s intervals. Mitochondria whose calcium-induced pore opening is effectively reversed by spermine to the tune of $\geq 80 \%$ were adjudged to be intact, retain their integrity, uncoupled and therefore, suitable for the assay.

To assess the effect of MPBD in the absence of calcium on $\mathrm{mPT}$, mitochondria were incubated in the presence of graded concentrations $(10-80 \mu \mathrm{g} / \mathrm{ml})$ of this compound in suspension buffer and rotenone and further energized with succinate. Effect of MPBD on MPT in the presence of calcium follows similar process only that calcium is appropriately added.

\section{Mitochondrial ATPase activity}

In triplicate, sucrose $(0.25 \mathrm{M}), \mathrm{KCl}(5 \mathrm{mM})$ and Tris- $\mathrm{HCl}(0.1 \mathrm{M})$ were dispensed into test tubes and the entire volume was made up to $1 \mathrm{ml}$ with distilled water. Adenosine triphosphate $(0.01 \mathrm{M})$ was added to all test tubes except the 'mitochondria only' tubes. Mitochondria $(0.5 \mathrm{mg} / \mathrm{ml})$ were added to all test tubes except the 'ATP only' tubes. Uncoupler $(25 \mu \mathrm{M}, 2,4$-dinitrophenol) was added to the designated tubes while $10 \%$ sodium dodecylsulphate (SDS) was added to the zero time tubes immediately after the addition of mitochondria. Varied concentrations of the test compound $(10-80 \mu \mathrm{g} / \mathrm{ml})$ were added to the test group containing ATP and mitochondria. The volume was made up and the test tubes were transferred to the shaker water bath and they were incubated at $27^{\circ} \mathrm{C}$ for $30 \mathrm{~min}$. After incubation, $1 \mathrm{ml}$ of SDS was added to all the tubes except the zero tubes to stop the reaction. Thereafter, $1 \mathrm{ml}$ each of the mixture was transferred into separate test tubes and $1 \mathrm{ml}$ each of $1.25 \%$ ammonium molybdate in $6.25 \% \mathrm{H}_{2} \mathrm{SO}_{4}$ and $9 \%$ ascorbate were added successively and the solution was allowed to stand for $30 \mathrm{~min}$. The absorbance of the blue color was read at $660 \mathrm{~nm}$. The concentration of inorganic phosphate was 
estimated from a $1 \mathrm{mM}$ solution of potassium dihydrogen phosphate, which was treated like the deproteinised mixture ${ }^{23}$.

\section{Cytochrome c release determination}

Cytochrome c release was determination as previously described ${ }^{24}$. Briefly, mitochondrial protein was preincubated in suspension buffer, rotenone and graded concentrations $(10-80 \mu \mathrm{g} / \mathrm{mL})$ of the test compound for $3.5 \mathrm{~min}$, thereafter, succinate was added. For the negative control, mitochondria were pre-incubated in the absence of calcium whilst in the positive control mitochondria were pre-incubated in the presence of calcium. The test compound was similarly treated in the absence of mitochondria and the incubation in each case lasted for $30 \mathrm{~min}$ after which the mixtures were spun at $12000 \mathrm{rpm}$ for $10 \mathrm{~min}$. The absorbance of the supernatant was read at $414 \mathrm{~nm}$ while the absorbance of the drug control was deducted from that of the test groups. The concentration of cytochrome $c$ release was estimated from the cytochrome c standard curve.

Membrane stabilizing activity

Heat-induced hemolysis

The procedure for the membrane stabilising assay was carried out as previously described ${ }^{25}$. The $2 \mathrm{ml}$ assay mixture contained $0.5 \mathrm{ml}$ hyposaline, $1.0 \mathrm{ml}$ of $0.15 \mathrm{M}$ sodium phosphate buffer $(\mathrm{pH} 7.4)$, varying volumes of isosaline and $0.5 \mathrm{ml}$ of bovine erythrocyte suspension. The drug control assay contained the above volumes of buffers and reagents without erythrocyte suspension while the blood control contained all the reagents except the drug. The reaction mixtures were incubated at $56^{\circ} \mathrm{C}$ for $30 \mathrm{~min}$ in a water bath and cooled to room temperature. Thereafter, mixtures were centrifuged at $3000 \mathrm{rpm}$ for $5 \mathrm{~min}$ and the absorbance of the supernatant was read at $560 \mathrm{~nm}$ against the test blank; the buffered sodium chloride solution served as blank. The percentage membrane stability activities were estimated as follows:

$\underline{100 \text {-(drug test value -drug control value) } \times 100}$

Control value

\section{Hypotonic solution-induced hemolysis}

Using the hypotonic solution-induced erythrocyte lysis,whole bovine blood was centrifuged and blood cells were washed three times with $154 \mathrm{mM} \mathrm{NaCl}$ in $10 \mathrm{mM}$ sodium phosphate buffer $(\mathrm{pH} 7.4)$ through centrifugation for $10 \mathrm{~min}$ at $3000 \mathrm{rpm}$. The sample tubes contained $0.50 \mathrm{ml}$ erythrocyte suspension mixed with $5 \mathrm{~mL}$ of hypotonic solution $(50 \mathrm{mM} \mathrm{NaCl})$ in $10 \mathrm{mM}$ sodium phosphate buffered saline $(\mathrm{pH} 7.4)$ containing the compound $(2.0 \mathrm{mg} / \mathrm{ml})$ or acetyl salicylic acid $(0.1 \mathrm{mg} / \mathrm{ml})$. The control sample consisted of $0.5 \mathrm{ml}$ of erythrocytes mixed with hypotonic buffered saline alone. The mixture was incubated for $10 \mathrm{~min}$ at room temperature, centrifuged for $10 \mathrm{~min}$ at $3000 \mathrm{rpm}$ and the absorbance of the supernatant was measured at $540 \mathrm{~nm}$. Acetyl salicylic acid was used as the positive control.

\section{Statistical analysis}


Representative profiles were used for the determination of mitochondrial permeability transition while other results were presented as mean \pm SD of triplicate determinations. Data were analyzed using descriptive statistics and one way ANOVA with Tukey multiple comparison post-hoc test to compare groups.

\section{Results}

In this study, a single compound from the $\mathrm{MeOH}$ extract of $A$. boonei was recognized as a mitochondrial pore opening inducer. This compound was therefore isolated, characterized and identified for further study.

\section{Characterisation of the isolated compound}

Brown amorphous solid; IR Vmax KBr cm${ }^{-1}: 3407.93,3378.652,2906$ and 1043.12. ${ }^{1} \mathrm{HNMR}_{(\mathrm{CDCl}}, 500$ $\mathrm{MHz}): \delta_{\mathrm{H}} 3.61-3.65(2 \mathrm{H}, \mathrm{m}, \mathrm{H}-1), 1.54-1.56(1 \mathrm{H}, \mathrm{m}, \mathrm{H}-2), 1.18(3 \mathrm{H}, \mathrm{H}-2 \mathrm{a}), 1.57-1.60(1 \mathrm{H}, \mathrm{m}, \mathrm{H}-3), 3.57-3.60$ $(2 \mathrm{H}, \mathrm{m}, \mathrm{H}-4), 1.19-1.23\left(2 \mathrm{H}, \mathrm{m}, \mathrm{H}-1^{\prime}\right), 1.34-1.39\left(2 \mathrm{H}, \mathrm{m}, \mathrm{H}-2^{\prime}\right), 0.92\left(3 \mathrm{H}, \mathrm{H}-3^{\prime}\right) .{ }^{1} \mathrm{HNMR}\left(\mathrm{CDCl}_{3}, 500 \mathrm{MHz}\right)$ : $\delta_{C} 64.71(\mathrm{C}-1), 34.87$ (C-2), 14.8 (C-2a), 47.5 (C-3), 62.78 (C-4), 25.90 (C-1'), 18.88 (C-2'), 10.13 (C-3').

\section{Identification of the isolated compound}

The ${ }^{1}$ HNMR spectrum of the isolated compound revealed non-aromatic signals and were analysed together with the aid of ${ }^{1} \mathrm{H} /{ }^{1} \mathrm{H}$ COSY and $\mathrm{HMBC}$ spectral data, which showed geminal oxygenated methylene proton multiplets at $\delta_{\mathrm{H}} 3.61-3.65(2 \mathrm{H}, \mathrm{m}, \mathrm{H}-1)$ with correlated to the resonance at $\delta \mathrm{c} 64.71$. A second geminal oxygenated methylene proton multiplet at $\delta_{\mathrm{H}} 3.57-3.60(2 \mathrm{H}, \mathrm{m}, \mathrm{H}-4)$ that correlated to the resonance at $\delta c 62.78$ was also observed. The ${ }^{1} \mathrm{HNMR}$ spectrum also revealed a methine resonance at $\delta_{\mathrm{H}} 1.54-1.56(1 \mathrm{H}, \mathrm{m}, \mathrm{H}-2)$ that correlated with the resonance at $\delta \mathrm{c} \otimes 34.87$ and coupled to the single methyl resonance at $\delta_{\mathrm{H}} 1.18(3 \mathrm{H}, \mathrm{d}, J=6.8 \mathrm{~Hz}, \mathrm{H}-2 \mathrm{a})$ that correlated to $\delta c 14.8$. A methine resonance at $\delta_{\mathrm{H}}$ 1.57-1.60 $(1 \mathrm{H}, \mathrm{m}, \mathrm{H}-3)$ that correlated to $\delta \mathrm{c} 47.50$ and which coupled to a propyl group at $\delta_{\mathrm{H}} 1.19-1.23(2 \mathrm{H}$, $\left.m, H-1^{\prime}\right)$ that correlated to $\delta c 25.90$ were also observed. A methylene resonance at $\delta_{H} 1.34-1.39(2 \mathrm{H}, \mathrm{m}, \mathrm{H}-$ $\left.2^{\prime}\right)$ that correlated to $\delta c 18.88$ and which coupled to a methyl resonance at $\delta_{H} 0.92\left(3 \mathrm{H}, \mathrm{H}-3^{\prime}\right)$ that correlated to $\delta c 10.13$ was observed. The ${ }^{1} \mathrm{H} /{ }^{1} \mathrm{H}$ COSY indicated the correlations of $\mathrm{H}-1$ to $\mathrm{H}-2 ; \mathrm{H}-2$ to $\mathrm{H}-$ 2a and $\mathrm{H}-3 ; \mathrm{H}-3$ to $\mathrm{H}-4 ; \mathrm{H}-1$ ' and $\mathrm{H}-2 ; \mathrm{H}-1$ ' cross peak to $\mathrm{H}-3$ and $\mathrm{H}-2$ '. Based on spectral data and $\mathrm{HMBC}$ correlations (Table 1, Figure 1) the isolated compound was identified as 2-methyl-3-propylbutane-1,4-diol (MPBD). The spectral data for MPBD are similar to those reported for 2,3-diethylbutane-1,4-diol ( $\mathrm{Ng}$ et al. 1984).

Table $1^{13} \mathrm{C}$ NMR, COSY and $\mathrm{HMBC}$ data of the isolated compound in $\mathrm{CDCl}_{3}$ at $500 \mathrm{MHz}$ 


\begin{tabular}{|c|c|c|c|c|}
\hline No & Type of Carbon & $\delta_{\mathrm{C}} \mathrm{ppm}$ & cosy & HMBC \\
\hline 1 & $\mathrm{CH}_{2} \mathrm{OH}$ & 64.71 & $\mathrm{H}-2, \mathrm{H}-3, \mathrm{H}-2 \mathrm{a}$ & $34.87,14.8,47.5$ \\
\hline 2 & $\mathrm{CH}$ & 34.87 & $\mathrm{H}-1, \mathrm{H}-3, \mathrm{H}-2 \mathrm{a}$ & $14.8,47.5,64.71$ \\
\hline $2 a$ & $\mathrm{CH}_{3}$ & 14.80 & $\mathrm{H}-2, \mathrm{H}-2, \mathrm{H}-3$ & $34.87,64.71,47.50$ \\
\hline 3 & $\mathrm{CH}$ & 47.50 & $\mathrm{H}-1^{\prime}, \mathrm{H}-4, \mathrm{H}-2$ & $25.90,18.88,62.78,34.87$ \\
\hline 4 & $\mathrm{CH}_{2} \mathrm{OH}$ & 62.78 & $\mathrm{H}-3$ & $47.50,34.87$ \\
\hline 1区 & $\mathrm{CH}_{2}$ & 25.90 & $H-2 ', H-3^{\prime}, \quad H-3$ & $47.50,18.88,10.13$ \\
\hline 2】 & $\mathrm{CH}_{2}$ & 18.88 & $\mathrm{H}-1^{\prime}, \mathrm{H}-3^{\prime}$ & $47.50,25.90,10.13$ \\
\hline 3区 & $\mathrm{CH}_{3}$ & 10.13 & $\mathrm{H}-2^{\prime}, \quad \mathrm{H}-1^{\prime}$ & $18.88,25.90$ \\
\hline
\end{tabular}

\section{Effects of 2-methyl-3-propylbutane-1,4-diol (MPBD) on mitochondrial permeability transition}

The isolated compound, 2-methyl-3-propylbutane-1,4-diol (MPBD), induced mPT in vitro in the absence of calcium at all concentrations used and this MPT induction was reversed in the presence of calcium in a concentration dependent manner. Ab initio, the MPT pore remained intact in the absence of calcium when the absorbance was monitored over a period of 12 minutes at 30 second intervals. However, a large amplitude opening of the pore was observed when calcium was added to the reaction medium and the system was energized with succinate. This pore opening induced by calcium was reversed by spermine, showing that the mitochondria isolated were intact, uncoupled and therefore, suitable for further use (Figure 2). In the presence of calcium, it could be observed that the calcium-induced opening of the pore was readily potentiated by MPBD at the highest concentration implying that this compound has additive induction of the MPT pore by calcium at the highest concentration (Figure $2 b$ ).

To understand the possible mechanism by which MPBD opens the mitochondrial pore, in vitro cytochrome $\mathrm{c}$ release, activity of mitochondrial ATPase and lipid peroxidation using the mitochondria as the lipid-rich media were monitored. The results showed MPBD to induce cytochrome $c$ release from the inner mitochondrial membrane in a concentration dependent manner. There was a significant $(P \otimes 0.001)$ increase in the level of cytochrome c release both at 40 and $80 \mu \mathrm{g} / \mathrm{mL}$ concentrations relative to the intact mitochondria without calcium (Figure 3a). The effect of MPBD on mitochondrial ATPase at physiological $\mathrm{pH}(7.4)$ is depicted in Figure $3 \mathrm{~b}$ which shows MPBD to significantly $(P \otimes 0.001)$ enhance mitochondrial ATPase activity at 20,40 and $80 \mu \mathrm{g} / \mathrm{ml}$ compared to the control. Significant differences between the effect of MPBD on mitochondrial ATPase activity at these concentrations were observed compared to the uncoupler ( $25 \mu \mathrm{M}, 2,4$-dinitrophenol). The effect of MPBD on lipid peroxidation in isolated mitochondria is depicted in Figure 3c. MPBD significantly $(P \otimes 0.001)$ prevented peroxidation of mitochondrial membrane lipids maximally at $80 \mu \mathrm{g} / \mathrm{ml}$. 
Figure 4 shows the effects of MPBD on erythrocyte membrane stability using both heat-induced and hypotonic solution-induced membrane destabilization. The results show that MPBD stabilize the erythrocyte membranes in a concentration dependent manner (Figure 4) in the heat-induced assay. However, the membrane stabilizing effect in the hypotonic solution-induced assay did not vary linearly with concentration of MPBD.

\section{Discussion}

The identification of the isolated compound was achieved on the basis of one-dimensional and twodimensional NMR spectroscopy and comparison with a similar alkyl di-substituted butane-1,4-diol in literature. There are no reports of isolation of alkyl di-substituted butane-1,4-diol from plants hence, this is reported here for the first time.. This is likely due to the simplicity of the molecule in contrast to the complex nature of plant-derived bioactive compounds. However, butane-1,4-diol and its derivatives have been employed in the synthesis of bioactive lactones ${ }^{26}$ and other fine chemicals ${ }^{27}$.

Mitochondrial permeability transition (mPT) pore opening has evolved as a pharmacological target in which cells can selectively be commuted to death. Once activated, $\mathrm{mPT}$ unselectively allows the passage of solutes and water across the inner membrane of mitochondria. The biphasic opening (short-term and long-term) of the pore has both physiological and pathological implications. The latter event may occur as a result of increases in calcium overload and reactive oxygen generation, ATP consumption and mitochondrial membrane depolarization as well as mitochondrial swelling and consequent release of proapoptotic proteins are important events that determine the life and death of mitochondria ${ }^{28}$. It is in this regard that naturally occurring compounds that can influence these processes are considered as pharmacological tools for determining the fate of cells.

Natural compounds that have been classified as mitochondrial permeants are either pro-oxidants or antioxidants $^{29}$. In this study, 2-methyl-3-propylbutane-1,4-diol (MPBD) was isolated from A. boonei. The interaction of MPBD with mitochondria and the concomitant release of cytochrome $c$ can likely be viewed in two ways; this is because of the alkyl and hydroxyl groups present on the compound. The alkyl group of natural products has been found to be a linker connecting another active portion that is considered to be pro-drugs carrying the active principle to mitochondria ${ }^{29}$. On the other hand, the functional group (hydroxyl group) is critical to the pharmacological role of some natural products. For example, the hemolytic effects of some saponins have been linked to the structural differences in the sapogenin (aglycone), sugar residue, and the number of $\mathrm{OH}, \mathrm{CH}_{2} \mathrm{OH}$ and $\mathrm{COOH}$ groups and where the $\mathrm{OH}$ group is ionisable to donate free proton, such compound may have antioxidant properties. Interestingly, alkanediols, the group of organic compounds to which MPBD belongs are protic molecules, meaning that they can donate protons ${ }^{30}$.

The opening of the MPT is a critical event in mitochondrial-mediated cell death. The large amplitude opening of the mitochondrial pore observed in the presence of MPBD showed that the MPT can be targeted using this compound both for pharmacological and clinical purposes especially in a variety of 
diseases where apoptosis is deregulated. Furthermore, the opening of the pore that was observed in the presence of calcium at the highest concentration showed that, at this concentration, MPBD potentiate calcium-induced opening of the pore.

One of the major reasons for long-term opening of the mitochondrial pore is the reduction in the mitochondrial membrane potential. To overcome this membrane potential loss, ATP synthase works in reverse mode, hydrolyzing ATP (as an ATPase enzyme). Therefore, a major outcome of MPT opening is the reversal of ATP synthase to function as an ATP hydrolyzing enzyme rather than synthesizing it ${ }^{28}$. In this study, MPBD was found to be a potent biological compound that significantly enhanced mitochondrial ATPase activity. This may be because it is able to cause mitochondrial uncoupling. Mitochondrial uncoupling, a pathway that enables proton re-entry into the matrix independent of ATP synthesis, is an energy dissipating cycling that occurs in all eukaryotic cells ${ }^{31}$.

Measured in this study as an increase in dephosphorylation efficiency of the mitochondrial ATPase, mitochondrial uncoupling is not entirely harmful because there is an inverse relationship between the proton leak and reactive oxygen species generation in isolated mitochondria. Therefore, therapeutic mitochondrial uncoupling is protective against some disorders such as obesity, diabetes, Parkinson's disease and aging ${ }^{32-36}$. Furthermore, recent findings on the involvement of mitochondrial ATPase in mPT formation may further make this enzyme a therapeutic target in a number of diseases.

Cytochrome $\mathrm{c}$ is a small soluble electron carrier heme-protein that facilitates cell energy production by transferring electrons from complex III to IV. A consequence of the large amplitude swelling of mitochondria is the release of cytochrome $\mathrm{c}$ into the cytosol, which results in cell apoptosis. In this study, MPBD significantly increased cytochrome $c$ release. Previous studies provided both clinical and experimental evidences of cytochrome $c$ release being an indication of cell death through either apoptosis or necrosis ${ }^{37}$.

Lipid peroxidation damages membrane phospholipids and can also act as a signal for cell death. In this study, MPBD prevented peroxidation of mitochondrial phospholipids, indicating that the cell deathinducing effect of MPBD was not via reactive oxygen species generation. The results also showed MPBD to prevent erythrocyte membrane damage. This indicates that, although the compound could induce mPT pore opening and subsequent cell death via the mitochondrial pathway, it also prevents membrane destabilisation. This shows the potential of MPBD as a good drug candidate for the induction of apoptosis in cells but not necrosis. A significant difference between apoptosis and necrosis is the cell morphology after death. This shows that the outer membranes of the cells being commuted to death are intact making treatment with this drug candidate selective thereby preventing further injury.

\section{Conclusion}

This study showed that the isolated compound, 2-methyl-3-propylbutane-1,4-diol (MPBD), from A. boonei caused mitochondrial-mediated cell death via the induction of $\mathrm{mPT}$, enhancement of mitochondrial 
ATPase and cytochrome $\mathrm{c}$ release but selectively prevented lipid peroxidation and erythrocyte membrane de-stabilisation. Therefore, the compound could find use in applications requiring selective cell death or as inhibitors of lipid peroxidation or as a proton donor.

\section{Declarations}

\section{Competing interest}

The authors declare that no competing interest exists

\section{Authors Contribution}

Olanlokun JO conceived and designed this study. Material preparation, data collection and analysis were performed by [Olanlokun JO and Popoola D], Spectroscopy was performed by [Bodede $\mathrm{O}$ and Moodley R] and interpreted by [Idowu OT]. The first draft of the manuscript was written by [Olanlokun JO] corrected by [Olorunsogo 00] and all authors commented on previous versions of the manuscript. All authors read and approved the final manuscript.

\section{References}

1. Adotey JPK, Adukpo GE, Boahen YO, Armah FA (2012) A Review of the Ethnobotany and Pharmacological Importance of Alstonia boonei DeWild (Apocynaceae). ISRN Pharmacol doi:10.5402/2012/587160.

2. Olanlokun JO, Olotu FA, Idowu OT, Agoni C, David OM, Soliman M, Olorunsogo OO (2020) In vitro, in silico studies of newly isolated tetrahydro-4-(7-hydroxy-10- methoxy-6, 14-dimethyl-15-mtolylpentadec-13-enyl) pyran-2-one and isobutyryl acetate compounds from Alstonia boonei stem bark. Journal of Molecular Structure 1216: 128225-128240.

3. Chinopoulos C, Adam-Vizi V (2010) Mitochondria as ATP consumers in cellular pathology Biochimica et Biophysica Acta (BBA) - Molecular Basis of Disease. 1802: 221-227.

4. Bernardi P, Rasola A, Forte M, Lippe G (2015) The mitochondrial permeability transition pore: channel formation by F-ATP synthase, integration in signal transduction, and role in pathophysiology. Physiol Rev 95: 1111-1155.

5. Olanlokun OJ, Oyebode TO, Olorunsogo OO (2017a) Effects of Vacuum Liquid Chromatography (Chloroform) Fraction of the Stem Bark of Alstonia boonei on Mitochondrial Membrane Permeability Transition Pore. J Basic Clin Pharma 8:221-225.

6. Olanlokun JO, Adejo D, Olorunsogo 00 (2017b) In vitro and in vivo effects of alpha stone, a polyherbal formula on mitochondrial permeability transition pore in rat liver. Int J Sc Res 6(11): 249253.

7. Šileikytė J, Roy S, Porubsky P (2010) Small molecules targeting the mitochondrial permeability transition. In: Probe Reports from the NIH Molecular Libraries Program, pp. 1-29, National Center for 
Biotechnology Information. http://www.ncbi.nlm.nih.gov/pubmed/25834903

8. Bernardi P, Di Lisa F 92015) The mitochondrial permeability transition pore: molecular nature and role as a target in cardioprotection. J Mol Cell Cardiol 78: 100-106.

9. Halestrap AP, Brenner C (2003) The adenine nucleotide translocase: a central component of the mitochondrial permeability transition pore and key player in cell death. Curr Med Chem 10: 1507 1525 .

10. Leung AW, Halestrap AP (2008) Recent progress in elucidating the molecular mechanism of the mitochondrial permeability transition pore. Biochim Biophys Acta 1777: 946 -952.

11. Elustondo PA, Nichols M, Negoda A, Thirumaran A, Zakharian E, Robertson GS, Pavlov EV (2016) Mitochondrial permeability transition pore induction is linked to formation of the complex of ATPase C-subunit, polyhydroxybutyrate and inorganic polyphosphate. Cell Death Dis 2:16070; doi:10.1038/cddiscovery.2016.70.

12. Cai J, Yang J, Jones DP (1998) Mitochondria control of apoptosis: the role of cytochrome $c$. Biochim Biophys Acta (BBA) - Bioenergetics.1366: 139-149.

13. Forrester SJ, Kikuchi DS, Hemandes MS, Xu Q, Griendlin KK (2018) Reactive Oxygen Species in Metabolic and Inflammatory Signaling. Circ Res 122: 877-902

14. Thongrakard V, Tencomnao T (2010) Modulatory effects of Thai medicinal plant extract on proinflammatory cytokines-induced apoptosis in human keratinocyte HaCaT cells Afr J Biotechnol 9: 4999-5003.

15. Kowalczyk T, Sitarek P, Skała E, Toma M, Wielanek M, Pytel D, Wieczfińska J, Szemraj J, Śliwiński T (2019) Induction of apoptosis by in vitro and in vivo plant extracts derived from Menyanthes trifoliata L. in human cancer cells. Cytotechnology 71:165-180.

16. Abbiw D (1990) Useful Plants of Ghana: West African Uses of Wild and Cultivated Plants. Kew, London: Intermediate Technology Publications, Royal Botanical Garden.

17. Villa CH, Pan DC, Zaitsev S, Cines DB, Siegel DL, Muzykantov VR (2015) Delivery of drugs bound to erythrocytes: new avenue for an old intravascular carrier. Ther Deliv 6: 795-826.

18. Vo NNQ, Fukushima EO, Muranaka T (2016) Structure and hemolytic activity relationships of triterpenoid saponins and sapogenins. J Nat Med (doi:10.1007/s11418-016-1026-9).

19. National Research Council (NRC). Guide for the Care and Use of Laboratory Animals. Publication no 85-23 (rev). National Institutes of Health, Bethesda, MD (1985).

20. Johnson D, Lardy H (1967) Isolation of rat liver and kidney mitochondria. Methods Enzymol. 10: 9496.

21. Lowry OH, Rosebrough NJ, Farr AL, Randall RJ (1951) Protein measurement with the Folin phenol reagent. J Bio Chem 193: 262-275.

22. Lapidus RG, Sokolove PM (1993) Spermine inhibition of the permeability transition of isolated rat liver mitochondria: An investigation of mechanism. J Biochem Biophys Meth 64: 246-253. 
23. Lardy HA, Wellman H (1953) The catalytic effect of 2, 4-dinitrophenol on Adenosine triphosphate hydrolysis by cell particles and soluble enzymes, J Biol Chem 201: 357-370.

24. Appaix F, Minatchy MN, Riva-Lavieille C, Olivares J, Antonsson G, Saks VA (2000) Rapid spectrophotometric method for quantitation of cytochrome $\mathrm{c}$ release from isolated mitochondria or permeabilized cells revisited. Bioch Biophy Acta 1457: 175-181.

25. Shinde UA, Phadke AS, Nair AM, Mungatiwar AA, Dikshit VJ, Sarsf MN (1989), Membrane stabilization activity: a possible mechanism of action for the anti-inflammatory activity of Cedrus deodara wood oil. Fitoterapia. 70: 251-257.

26. Ng GS, Yuan LC, Jakovac IJ, Jones JB (1984) Enzymes in organic synthesis-29: Preparations of enantiomerically pure cis-2, 3-and 2, 4-dimethyl lactones via horse liver alcohol dehydrogenasecatalyzed oxidations. Tetrahedron 40: 1235-1243.

27. Trinh T, Tordil HB, Wahl EH, Rinker JL, Demeyere HJM, Declercq MJ, Sivik MR (2002) U.S. Patent No. $6,369,025$. Washington, DC: U.S. Patent and Trademark Office.

28. Sileikyte J, Forte M (2019) The Mitochondrial Permeability Transition in Mitochondrial Disorders. Oxid Med Cell. Long https://doi.org/10.1155/2019/3403075.

29. Biasutto L, Mattarei A, La Spina M, Azzolini M, Parrasia S, Szabo I, Zoratti M (2019) Strategies to target bioactive molecules to subcellular compartments. Focus on natural compounds. Eur J Med Chem 181: 111557. Doi: 10.1016/j.ejmech.2019.07.060

30. Vo NNQ, Fukushima EO, Muranaka T (2017) Structure and hemolytic activity relationships of triterpenoid saponins and sapogenins. J Nat Med 71(1): 50-58

31. Davies KM, Strauss M, Daum B (2011) Macromolecular organization of ATP synthase and complex I in whole mitochondria. Proc Nat Acad Sci USA 108:14121-14126.

32. Korshunov SS, Skulachev VP, Starkov AA (1997) High protonic potential actuates a mechanism of production of reactive oxygen species in mitochondria. FEBS Letters 416:15-18.

33. Caldeira da Silva CC, Cerqueira FM, Barbosa LF, Medeiros MHG, Kowaltowski AJ (2008) Mild mitochondrial uncoupling in mice affects energy metabolism, redox balance and longevity. Aging Cell 7: 552-560.

34. Islam R, Yang L, Sah M (2012) A neuroprotective role of the human uncoupling protein 2 (hUCP2) in a Drosophila Parkinson's disease model. Neurobiol Dis 46; 137-146.

35. Tao H, Zhang Y, Zeng X, Shulman GI, Jin S (2014) Niclosamide ethanolamine-induced mild mitochondrial uncoupling improves diabetic symptoms in mice. Nature Medicine. 20:1263-1269.

36. Busiello RA, Savarese S, Lombardi A (2015) Mitochondrial uncoupling proteins and energy metabolism Frontiers in Physiol. 6: 36.

37. Eleftheriadis T, Pissas G, Liakopoulos V, Stefanidis L (2016) Cytochrome c as a Potentially Clinical Useful Marker of Mitochondrial and Cellular Damage. Front. Immunol ,https://doi.org/10.3389/fimmu.2016.00279. 

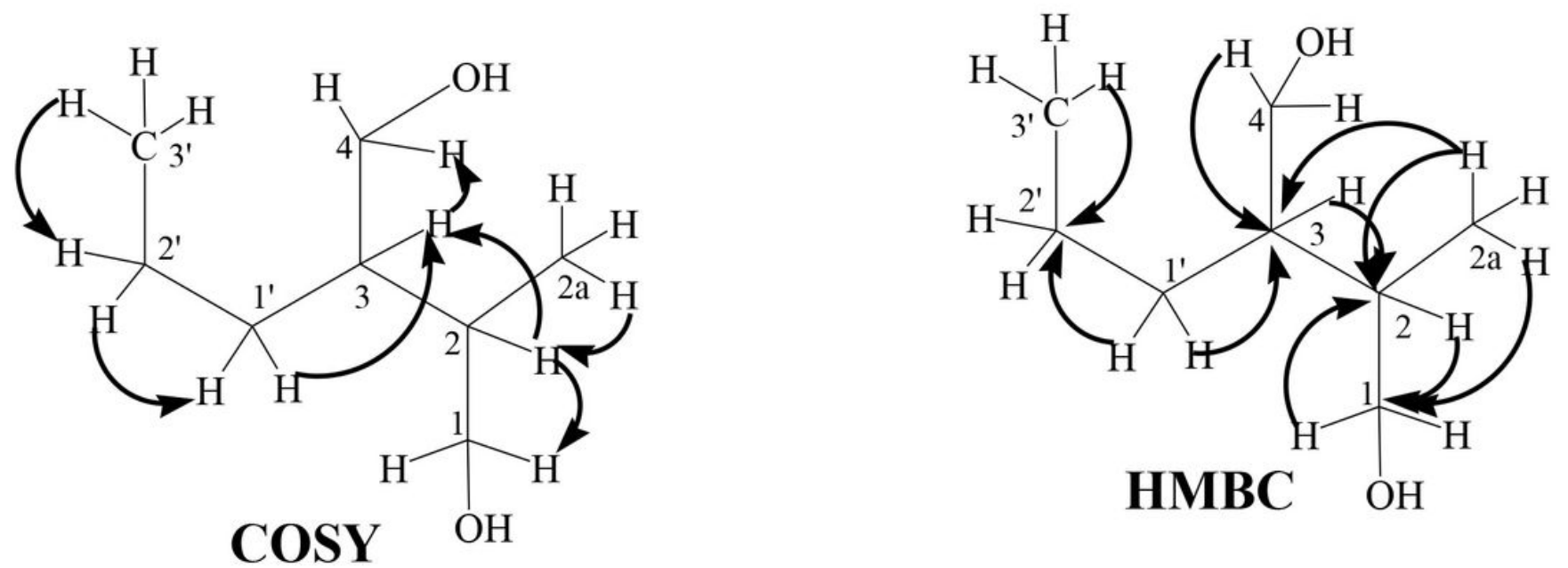

Figure 1

Correlation spectroscopy (COSY) and HMBC correlations for the isolated compound

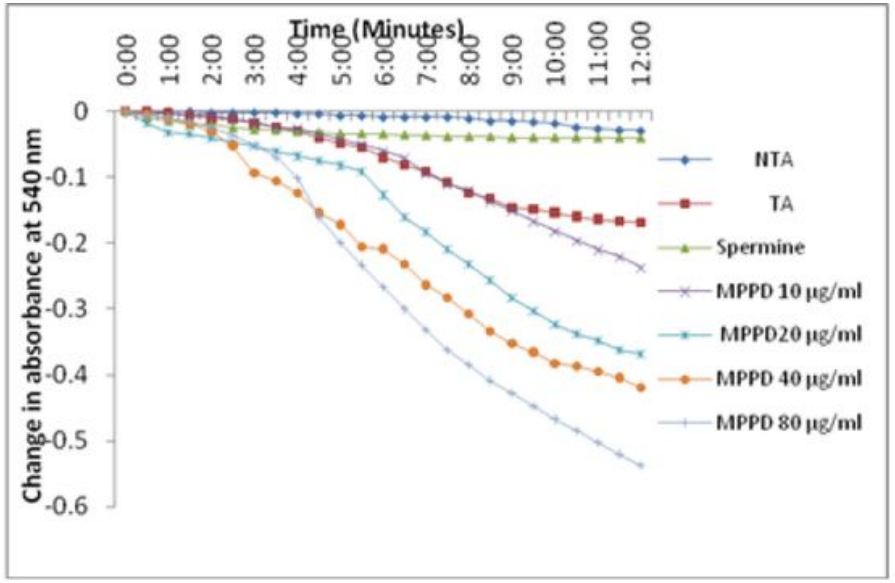

A

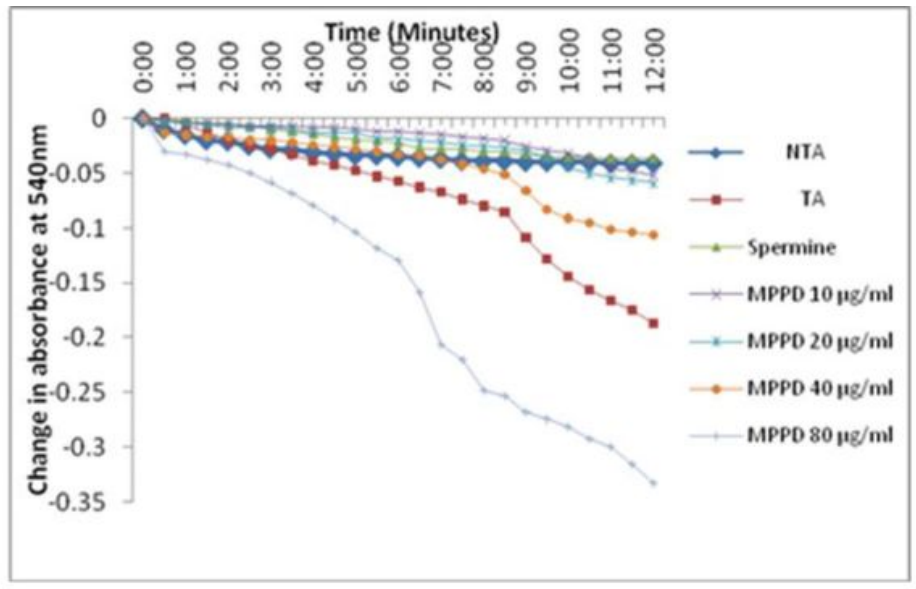

B

Figure 2

Representative profile showing the in vitro effects of 2-methyl-3-propylbutane-1,4-diol (MPBD) on mitochondrial permeability transition pore opening in the absence (A) and in the presence (B) of calcium. 


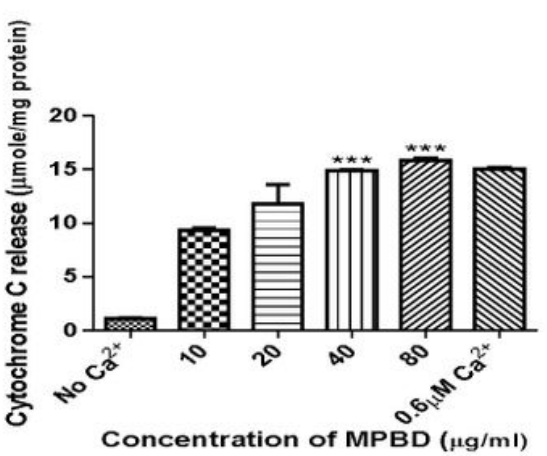

A

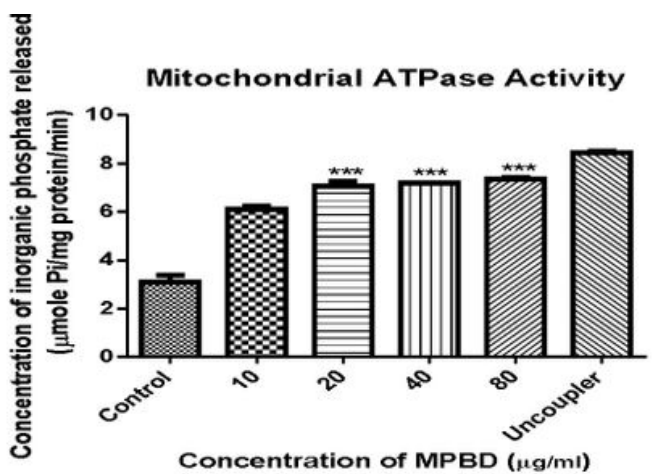

B

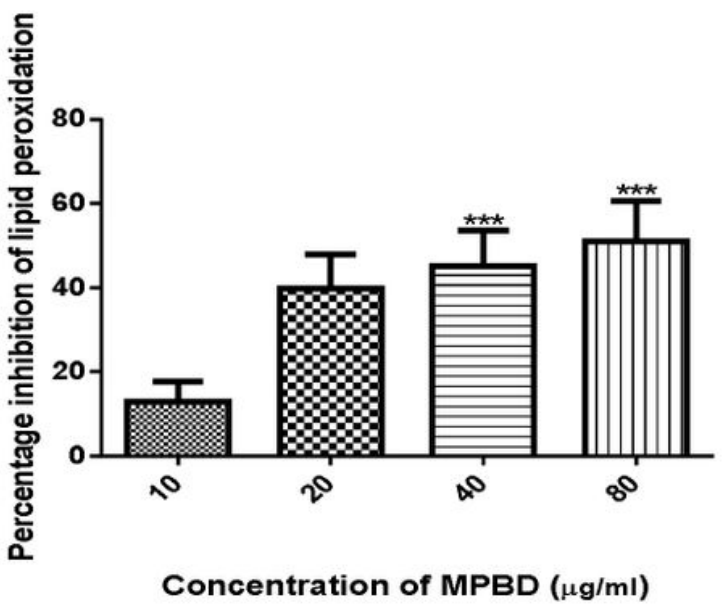

C

Figure 3

Effects of 2-methyl-3-propylbutane-1,4-diol (MPBD) on cytochrome c release (A), mitochondrial ATPase (B) and lipid peroxidation (C). *** $-P \otimes 0.001 \mathrm{vs} \mathrm{no} \mathrm{Ca}^{2+}$ in $\mathrm{A}$, control in $\mathrm{B}$ and $10 \mu \mathrm{g} / \mathrm{ml}$ in $\mathrm{C}$.

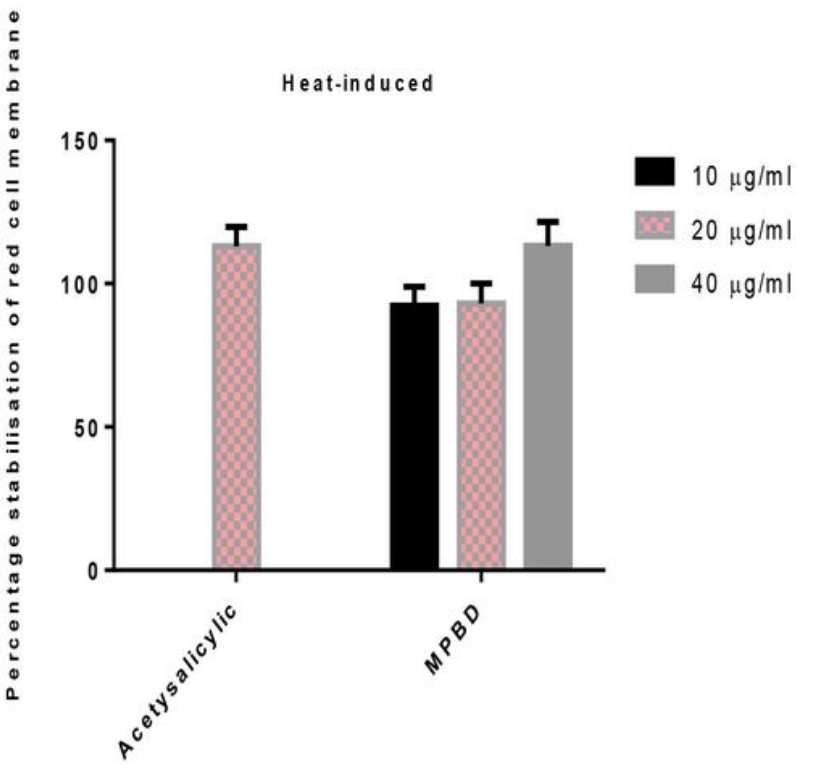

Drugs

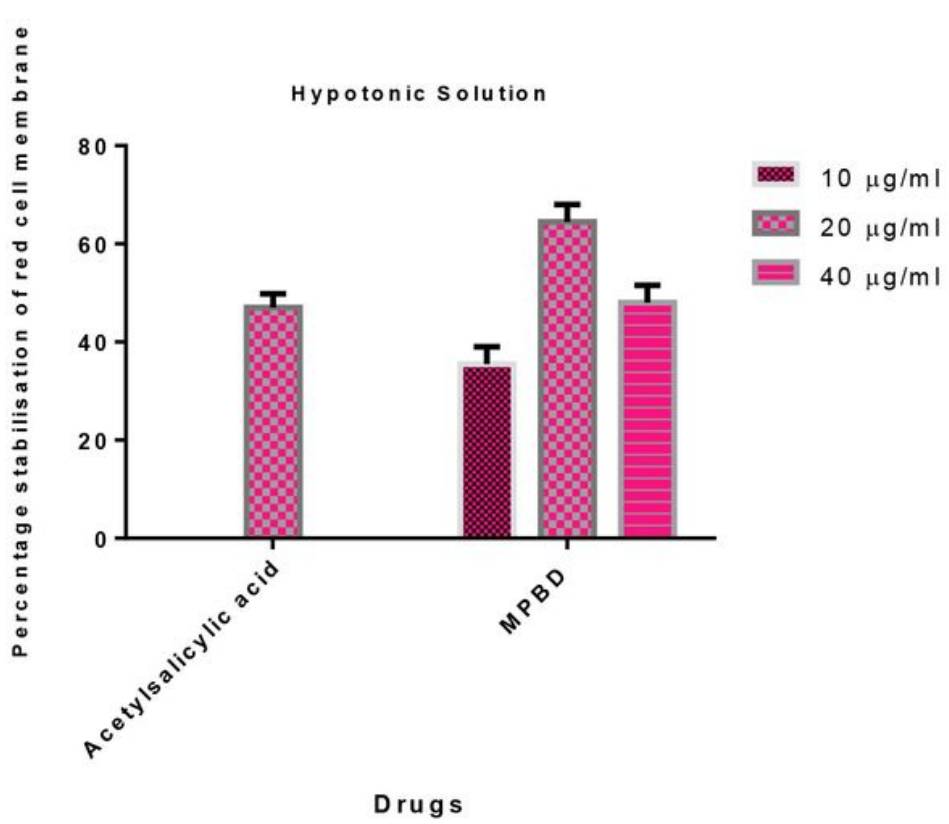


Figure 4

Effects of 2-methyl-3-propylbutane-1,4-diol (MPBD) on erythrocyte membrane stabilizing assay using the heat-induced and hypotonic solution-induced assay.

\section{Supplementary Files}

This is a list of supplementary files associated with this preprint. Click to download.

- DavPTLC1H.pdf

- DavPTLC13C.pdf

- DavPTLCCOSY.pdf

- DavPTLCHMBC.pdf

- DavPTLCHSQC.pdf 